\title{
JOLANTA KUROSZ \\ Ćwiczenia z teologii pastoralnej dla studentów uniwersyteckich wydziałów teologicznych
}

Wśród wielu zadań spoczywających na świeckich wiernych Konstytucja dogmatyczna o Kościele Lumen gentium wymienia uczestnictwo w szczególnym powołaniu, którego zadaniem jest czynić obecnym i aktywnym Kościót w takich miejscach i w takich okolicznościach, gdzie jedynie przy ich pomocy stać się on może solq ziemi (KK 33). W innym miejscu ojcowie soborowi wzywaja ich, by poprzez ciagłe studiowanie przygotowali się do dialogu ze światem i ludźmi (por. KDK 43). Przegląając materiały z Sympozjum Pastoralistów Polskich w Kielcach i Nysie $2001 \mathrm{r}$. , podczas których omawiano m.in. projekt ćwiczeń z teologii pastoralnej, odnosi się wrażenie, że cała uwaga została skupiona na alumnach seminariów duchownych. O charakterze kształcenia ludzi świeckich wspomina się marginalnie. Podczas sympozjum w Nysie ks. prof. Maciej Ostrowski wygłosił referat pt. Potrzeba i znaczenie ćwiczen z teologii pastoral$n e^{2}$, który w większości poświęcił kształceniu pastoralnemu przyszłych kapłanów. Prelegent zauważyl, że zagadnienie kształcenia teologicznego świeckich zostało pominięte we wskazanych przez niego dokumentach. Jeżeli jeszcze zrozumieć można brak tej tematyki w dokumentach dotyczących formacji kapłańskiej, tak już zdumienie budzić musi pominięcie jej w dokumentach II Polskiego Synodu Plenarnego. Śledząc dyskusję, która odbyła się podczas sympozjum w

${ }^{1}$ Por. Duszpasterstwo a wyzwania XXI wieku. Materiały z Sympozjum Pastoralistów Polskich 22-24 kwietnia 2001. Red. J. Ostrowski. Kielce 2001; Status naukowy teologii pastoralnej. Materiały z sympozjum polskich pastoralistów. Nysa 8 -9 października $2001 \mathrm{r}$. Red. J. Mikoła jec. Opole 2003 s. $47-81$.

${ }^{2}$ Por. M. Ostrowski: Potrzeba i znaczenie ćwiczeń z teologii pastoralnej. W: Status naukowy teologii..., dz. cyt., s. $47-57$. 
Nysie, zauważyć można różne pojmowanie ćwiczeń $z$ teologii pastoralnej ${ }^{3}$. Pojawiające się różnice, które dotyczyly terminologii i celu ćwiczeń spowodowały, że podczas tego spotkania nie wypracowano jednolitego stanowiska.

W polskiej literaturze można zauważyć brak szerszego opracowania, dotyczacego kształcenia pastoralnego świeckich studentów teologii na uniwersytetach. W materiałach wydanych po sympozjum w Kielcach zamieszczono w formie aneksu dokument autorstwa mgr Jadwigi Olejnikowej i ks. prof. dr hab. Adama Przybeckiego pt. Projekt pedagogiczny praktyki zawodowej dla studentów Wydziału Teologicznego Uniwersytetu im. A. Mickiewicza w Poznaniu ${ }^{4}$. Szersze omówienie tego projektu zostało przedstawione w drugim tomie czasopisma „Teologia Praktyczna”.

Celem niniejszego opracowania jest ukazanie znaczenia ćwiczeń w kształceniu uniwersyteckim, próba umiejscowienia ich w kształceniu pastoralnym oraz przedstawienie celów ćwiczeń z teologii laikatu i apostolstwa realizowanych wśród studentów świeckich IV roku w ramach specjalizacji katechetycznopastoralnej na Wydziale Teologicznym UAM w Poznaniu.

\section{I. Ćwiczenia elementem kształcenia uniwersyteckiego}

Ćwiczenia obok wykładów, seminariów, proseminariów, praktyk zawodowych dla studentów świeckich, duszpasterskich dla kleryków oraz pedagogicznych wchodzą w skład procesu dydaktycznego wyższych uczelni. Proces dydaktyczny jest ciagiem systematycznych czynności nauczycieli i uczniów (studentów), umożliwia tym drugim, opanowanie wiedzy o świecie, wyrabia sprawność w jej stosowaniu, rozwija zdolności i zainteresowania, kształtuje przekonania oraz postawy ${ }^{6}$. Proces kształcenia będący częścią składową procesu dydaktycznego zakłada świadome i celowe działanie, które ma doprowadzić do osiagnięcia zamierzonych efektów. Proces kształcenia pozostaje w zależności od celów, treści, zasad kształcenia oraz uwzględnia uwarunkowania osobowościowe zarówno poszczególnych uczestników, jak i grupy biorącej udział w procesie kształcenia, przy czym treści i zasady są elementami, które mają największy

${ }^{3}$ Por. Głosy w dyskusji. W: Status naukowy.., dz. cyt., s. $69-81$.

${ }^{4}$ Por. J. Olenikowa, A. Pr zybecki: Projekt pedagogiczny praktyki zawodowej dla studentów Wydziału Teologicznego Uniwersytetu im. A. Mickiewicza w Poznanitu. W: Duszpasterstwo a wyzwania..., dz. cyt., s. $151-154$.

${ }^{5}$ Por. A. Przybecki: Praktyki zawodowe dla świeckich studentów teologii. Projekt i pierwsze doświadczenia. „Teologia Praktyczna”. T. 2: 2001 s. 134-146 oraz J. Olejnik owa: Praktyki zawodowe dla świeckich studentów teologii. Projekt i pierwsze doświadczenia, tamże, s. 147-157.

${ }^{6}$ Por. W. Ok oń: Nowy slownik pedagogiczny. Warszawa 2001 s. 315. 
wpływ na czynności studentów i nauczycieli. Podstawowym warunkiem właściwego funkcjonowania procesu dydaktycznego jest uwzględnienie zasad ksztalcenia, określenie celów ogólnych i szczególowych (operacyjnych), wlaściwy dobór treści oraz metod kształcenia. Cele ogólne wskazuja kierunki dażeńn, a operacyjne precyzyjnie określają to, co ma być osiągnięte. Przyjęte cele realizowane sa przy pomocy odpowiednio dobranych treści z uwzględnieniem zasad kształcenia. Cele operacyjne pozwalają na odpowiedni dobór treści, które sa zdobywane przez studentów w toku czynności składających się na proces kształcenia. Treści nauczania winny być tak dobrane, aby rozwijały siły i zdolności poznawcze studentów, wytwarzały i rozwijały zainteresowania, dawały bodźce do samokształcenia, były dostosowane do możliwości percepcyjnych uczestników zajęć. Układ treści nauczania w danej jednostce dydaktycznej, może być trojaki: koncentryczny, linowy i spiralny ${ }^{7}$.

Operacjonalizacja celów, czyli przekształcenie celów ogólnych w operacyjne sprawia, że cel nauczania ulega sprecyzowaniu, uszczegółowieniu, konkretyzacji, a osiaggający ten cel upodmiotowieniu. Dokonując operacjonalizacji celów należy zachować umiar w uszczególowianiu, zachowaniu otwartości zbioru celów operacyjnych i celu ogólnego. Cele operacyjne podlegają także uporządkowaniu, czyli hierarchicznej klasyfikacji zwanej taksonomią celów nauczania. Zapewnia ona równowage między niższymi i wyższymi celami operacyjnymi nauczania. Taksonomia celów nauczania powinna przebiegać na poziomie wiadomości i umiejętności. Poziom wiadomości obejmuje zapamiętywanie oraz zrozumienie wiadomości, a poziom umiejętności zawiera stosowanie zdobytej wiedzy w sytuacjach typowych i problemowych ${ }^{8}$. W ostatnim czasie taksonomia celów kształcenia w wyższych uczelniach, kładzie największy nacisk na cele poznawcze zapewniające studentom uzyskanie gruntownej i rzetelnej wiedzy ogólnej oraz specjalistycznej, nadto rozwijanie umiejętności samodzielnego i twórczego myślenia, sprawnej twórczej wyobraźni, na kształcenie zmysłu ob-

\footnotetext{
${ }^{7} \mathrm{~W}$ układzie koncentrycznym chodzi o taki dobór treści nauczania, by były one dostosowane do ogólnej zasady lub idei stanowiącej ośrodek dookoła, którego skupia się pewna całość materiału danej idei. W układzie liniowym zakres treści nauczania nie przekracza granic danego przedmiotu, a materiał przedmiotu jest ułożony systematycznie i stanowi jednolity ciąg logicznie powiązanych treści nauczania. Treści nauczania w układzie spiralnym są tak ułożone, że coraz bardziej rozszerzają się w zależności od tego, jak wydłuża się promień otwartych kół tego układu. Treści nauczania powtarzają się częściowo na poszczególnych poziomach, są one zrazem utrwalane i pogłębiane o nowe elementy - por. J. Zborowski: Koncentryczny, liniowy i spiralny układ treści nauczania. W. Encyklopedia pedagogiczna. Warszawa 1997 s. 283-285; A. Siemak-Tylkowska: Treści nauczania - teorie doboru treści ksztalcenia. W: Encyklopedia..., dz. cyt., s. 854; D. Jackowiak: Metodyczne aspekty zajęć akademickich. „Colloquia Theologica Adalbertina”. Practica et Canonica. Vol. II: 2000 z. 1 s. $27-30$.

${ }^{8}$ Por. B. Niemierk o: Między ocena szkolna a dydaktykq. Bliżej dydaktyki. Warszawa 1997 s. $75-167$.
} 
serwacyjnego, krytycyzmu i odwagi w podejmowaniu decyzji. Cele ogólne i operacyjne ćwiczeń, które podlegają w/w zasadom, muszą być także zgodne $\mathrm{z}$ założeniami dydaktyki szkoły wyższej, ta zaś domaga się, by treść edukacji spełniala trzy funkcje:

- zapewniała młodzieży akademickiej poznanie świata, zwlaszcza jego dziedzin związanych z kierunkiem studiów oraz kierowanie się dyrektywami nauki w życiu,

- ksztalciła młodzież do stosowania metod naukowych,

- przygotowywała studentów do działalności praktycznej w obrębie wybranej specjalizacji ${ }^{9}$.

Ogólne normy postępowania dydaktycznego, których przestrzeganie umożliwia realizację celów kształcenia, to zasady kształcenia. Odnoszą się one do działalności nauczycieli (nauczania), jak i do uczniów (uczenie się). Do najczęściej wymienianych zasad kształcenia należą: zasada systematyczności, logicznej kolejności i stopniowania trudności, poglądowości, samodzielności (świadomości i aktywności), związku teorii z praktyka, efektywności, operatywności wiedzy, związku indywidualizacji z socjalizacja ${ }^{10}$.

Uwzględniając powyższe zasady, do celów ogólnych ćwiczeń zalicza się: rozwijanie umiejętności posługiwania się zdobytą wiedzą (m.in. na wykładach) oraz kształtowanie nawyków i przyzwyczajeń; wykorzystanie wiedzy do rozwiazywania problemów; przygotowanie studentów do prowadzenia badań i calościowego ujęcia treści wykładu; uzupełnienie treści wykładu, rozwijanie zdolności i zainteresowań poznawczych, wdrażanie do posługiwania się literaturą fachowa.

Wszystkie w/w cele ćwiczeń sa zgodne $\mathrm{z}$ celami ogólnymi kształcenia w szkole wyższej, ale ksztaltowanie umiejętności, nawyków oraz przyzwyczajeń jest wśród nich szczególnie charakterystyczne i ważne dla tej formy procesu dydaktycznego. Zdobyte przez młodzież w toku studiów uniwersyteckich umiejętności i nawyki, uzdalniaja ją do posługiwania się wiedza naukowa, dzięki której działanie staje się celowe, skuteczne i ekonomiczne ${ }^{11}$. Cele ogólne wymagaja od prowadzacego ćwiczenia odpowiedniego przygotowania pod względem merytorycznym i metodycznym. Przygotowanie do tego rodzaju zajęć jest jednak różne od przygotowania związanego $\mathrm{z}$ prowadzeniem innych form ksztalcenia uniwersyteckiego. Ćwiczenia bowiem różnią się od seminariów, których zada-

\footnotetext{
${ }^{9}$ Por. W. Okoń: Dydaktyka szkoły wyższej. W. Encyklopedia..., dz. cyt., s. 136-140.; T. Lewowicki: Proces ksztalcenia w szkole wyższej. Warszawa 1988 s. 13.

${ }^{10}$ Por. W. Okoń: Nowy słownik..., dz. cyt., s. 463.

${ }^{11}$ Por. W. Okoń: Elementy dydaktyki szkoly wyższej. Warszawa 1973 s. $230-231$.
} 
niem jest przygotowanie studentów do samodzielnego poszukiwania źródłowych materiałów naukowych, ksztaltowania umiejętności dokonywania krytycznej analizy wybranych tekstów, samodzielnego ich opracowania, rozwijania umiejętności prezentacji przygotowanego problemu. Wykorzystanie zatem metod problemowych jest tym, co szczególnie charakteryzuje seminaria, proseminaria i konwersatoria $^{12}$.

Ćwiczenia różnią się także od praktyk zawodowych. Celem tych ostatnich jest m.in. przygotowanie studentów do praktycznego udziału w kształtowaniu dziedzin życia zgodnie z kierunkiem studiów, pogłębianie wiedzy oraz jej weryfikacja w praktycznym zastosowaniu ${ }^{13}$.

Ćwiczenia nie mogą być również dodatkową godziną wykładową, podczas której studenci zdobędą w sposób bierny kolejną porcję wiedzy. Tym, co odróżnia ćwiczenia od wykładów jest aktywny udział studentów, od którego w dużej mierze zależy realizacja zamierzonych celów.

Ważnym elementem w prowadzeniu ćwiczeń są środki dydaktyczne, które pełnią funkcję poznawczo-ksztalcącą oraz motywującą pracę studentów. Ułatwiają także aktywne zaangażowanie się studentów w czasie zajęć, a wykonane przez studentów prace, np. schematy na dużych arkuszach papieru, przy pomocy środków dydaktycznych, umożliwiają nawiązanie w latwy sposób podczas kolejnych zajęć do treści z poprzednich ćwiczeń. Epidiaskop, folie, arkusze szarego papieru, kartki A4, małe karteczki, flamastry, klej oraz przygotowane wcześniej materiały do pracy w grupach to podstawowe środki dydaktyczne, które w prosty sposób aktywizują studentów podczas zajęć. W zależności od stosowanych podczas ćwiczeń metod wyróżnia się m.in. cztery podstawowe rodzaje tychże zajęć, niezależnie od dziedziny naukowej w ramach, której są one realizowane. Są to ćwiczenia: analityczne, poszukujace, dyskusyjne, ćwiczenia-debaty ${ }^{14}$. Wśród metod powinny przeważać takie, które aktywizują pracę studentów podczas zajęć. Do metod aktywizujących należy m.in. praca w grupach. Zaletą tej metody jest aktywizacja wszystkich studentów, pod warunkiem, że wielkość grupy nie przekroczy czterech osób. Praca w grupach umożliwia różne sposoby wypowiedzi wszystkich uczestników na dany temat w różnorodnej formie. Tak prowadzone ćwiczenia dają również możliwość całościowego spojrzenia na zagadnienie, pod warunkiem, że grupy opracowują i przedstawiają różne aspekty danego

${ }^{12}$ Por. W. Okoń: Dydaktyka szkoly wyższej..., dz. cyt. s. 139; D. Jackowiak: Metodyczne aspekty...,dz. cyt. s. 30.

${ }^{13}$ Por. W. Ok oń: Elementy ..., dz. cyt., s. 292-293.

${ }^{14}$ Por. E. Adamiak: Ćwiczenia z teologii dogmatycznej. Programy, źródła, metody. Wykład podczas Sympozjum dogmatyków wyższych uczelni kościelnych w Polsce. Gietrzwałd, 1921.09.2002 s. 4 [mps]. 
zagadnienia. Inną zaletą pracy $w$ grupach jest kształcenie umiejętności pracy zespołowej. Metody, jak i środki są zależne od możliwości i umiejętności prowadzącego ćwiczenia, tematyki zajęć oraz grupy biorącej udzial w zajęciach.

\section{Rola ćwiczeń w kształceniu pastoralnym}

Specyfika ćwiczeń, realizowanych $\mathrm{w}$ ramach kształcenia pastoralnego na wyższych uczelniach, musi odpowiadać naukowemu charakterowi teologii pastoralnej oraz wspomnianym wcześniej normom, składającym się na proces dydaktyczny realizowany w szkołach wyższych. Adhortacja apostolska Pastores dabo vobis podaje definicję tej dyscypliny teologicznej, określajac ja jako naukowa refleksję o codziennym wzrastaniu Kościoła w mocy Ducha Świętego w kontekście historii. Teologia pastoralna jest nie tylko umiejętnościq, zespołem wskazań, doś wiadczén i metod. Ma status pełnoprawnej dyscypliny teologicznej, ponieważ czerpie $z$ wiary zasady i kryteria działalności duszpasterskiej Kościoła w historii; Kościoła, który »rodzi« każdego dnia Kościól, jak to trafnie ujmuje św. Beda Czcigodny: »Nam et Ecclesia quotidie gignit Ecclesiam «. Ws ród tych zasad i kryteriów szczególnie ważne miejsce zajmuje ewangeliczne rozeznanie sytuacji społeczno-kulturalnej i kościelnej, w której prowadzona jest działalność duszpasterska ${ }^{15}$.

W myśl powyższej definicji, uwzględniając specyfikę ćwiczeń, celem ogólnym calego bloku ćwiczeń $w$ ramach kształcenia pastoralnego jest rozwijanie umiejętności posługiwania się zdobytą wiedza, dotycząca codziennego wzrastania Kościoła w mocy Ducha Świętego w kontekście historii. Cele pośrednie, ułatwiające osiagniecie celu ogólnego są następujące: kształtowanie umiejętności rozeznawania sytuacji społeczno-kulturalnej i kościelnej, w której prowadzona jest działalność duszpasterska Kościoła; analiza zasad i kryteriów działalności duszpasterskiej Kościoła; analiza działalności duszpasterskiej Kościoła oparta m.in. na obserwacji i doświadczeniu zdobytym przez studentów w trakcie praktyk zawodowych (duszpasterskich); analiza i pogłębienie znajomości dokumentów Kościoła pod kątem pastoralnym; rozwijanie umiejętności posługiwania się zdobyta wiedza $z$ zakresu teologii pastoralnej w celu opracowania poszczególnych problemów; kształtowanie umiejętności formułowania duszpasterskich wniosków i postulatów oraz całościowego spojrzenia na Kościół jako komunię.

\footnotetext{
${ }^{15}$ Jan Paweł II: Adhortacja apostolska Pastores dabo vobis. Libreria Editrice Vaticana 1992 nr 57.
} 
Opracowując cele operacyjne ćwiczeń w ramach ksztalcenia pastoralnego, należy uwzglẹdnić zarówno rozróżnienie pomiędzy ćwiczeniami a praktykami zawodowymi (duszpasterskimi), jak i ich komplementarność w procesie ksztalcenia pastoralnego oraz docenić doświadczenia uczestniczących $\mathrm{w}$ zajęciach studentów. Oprócz tego tematyka ćwiczeń musi być osadzona w programie studiów. Dla uniwersyteckich wydziałów teologicznych stosujących Europejski System Transferu Punktów (ECTS), zostały jasno określone standardy i program poszczególnych dyscyplin naukowych, w tym teologicznych. Programy zostały dostosowane do charakteru studiów oraz specjalizacji katechetyczno-pastoralnej, dialog społeczny i kapłańskiej. Wśród studentów specjalizacji kapłańskiej realizuje się nadto wytyczne zawarte w Ratio studiorum.

Jeżeli ćwiczenia są powiązane $z$ wykładem, wówczas ich program uwzględnia również koncepcję prowadzącego wykłady. Precyzyjnie określone cele ćwiczeń, świadczą o tym, że ćwiczenia nie mogą być miejscem przygotowania lub podsumowania praktyk zawodowych oraz praktyk duszpasterskich. Zorganizowanie tych ostatnich leży w kompetencji seminariów ${ }^{16}$. Nie oznacza to jednak, że prowadzący ćwiczenia nie może do nich nawiązywać, wręcz przeciwnie, powinien to czynić, o ile realizowane cele $w$ trakcie zajęć będą powiązane $z$ nabytymi przez studentów w czasie obywania praktyk doświadczeniami i umiejętnościami. Taka sytuacja ma wlaśnie zastosowanie $\mathrm{w}$ trakcie prowadzenia ćwiczeń $\mathrm{z}$ teologii pastoralnej. Różnice między ćwiczeniami a praktykami zawodowymi dla studentów świeckich oraz duszpasterskimi dla kleryków przedstawia poniższa tabela. Cele praktyk duszpasterskich zostały opracowane w oparciu o wspomniane już Zasady formacji kapłańskiej w Polsce. Ratio studiorum ${ }^{17}$.

\begin{tabular}{|c|c|c|}
\hline \multicolumn{3}{|c|}{ Cel główny } \\
\hline $\begin{array}{c}\text { Ćwiczenia } \mathrm{z} \text { teologii } \\
\text { pastoralnej }\end{array}$ & $\begin{array}{c}\text { Praktyki zawodowe } \\
\text { dla studentów świeckich }\end{array}$ & $\begin{array}{c}\text { Praktyki duszpasterskie } \\
\text { dla kleryków }\end{array}$ \\
\hline $\begin{array}{l}\text { Rozwijanie umiejętności posłu- } \\
\text { giwania się zdobyta wiedza } \\
\text { dotycząca codziennego wzra- } \\
\text { stania Kościoła w mocy Ducha } \\
\text { Świętego w kontekście historii }\end{array}$ & $\begin{array}{l}\text { Weryfikacja zdobytej wiedzy } \\
\text { teoretycznej i praktycznej } \\
\text { studentów III roku w sytuacji } \\
\text { zadań realizowanych przez } \\
\text { instytucje i placówki: służby } \\
\text { zdrowia, pomocy społecznej } \\
\text { mass mediów, placówek reso- }\end{array}$ & $\begin{array}{l}\text { Wykorzystanie, zdobytej dzięki } \\
\text { studium teologii pastoralnej, } \\
\text { wiedzy w zastosowaniu } \\
\text { praktycznym. }\end{array}$ \\
\hline
\end{tabular}

\footnotetext{
${ }^{16}$ Na Wydziale Teologicznym UAM w Poznaniu praktyki duszpasterskie są realizowane w ścisłym porozumieniu między uczelnią a seminarium duchownym.

${ }^{17}$ Por. A. Przybecki: Praktyki zawodowe..., dz. cyt., s. 134-146; J. Olejnikowa, dz. cyt., s. 147-157; Kongregacja ds. Wychowania Katolickiego: Zasady formacji kapłańskiej W Polsce. Ratio studiorum. Częstochowa 1999 s. 110-118.
} 


\begin{tabular}{|c|c|c|}
\hline & $\begin{array}{l}\text { cjalizacyjnych, parafii itp. a } \\
\text { także w poszerzeniu grupy } \\
\text { profesjonalistów o teologów } \\
\text { działających na rzecz drugiego } \\
\text { człowieka. }\end{array}$ & \\
\hline \multicolumn{3}{|c|}{ CELE POŚREDNIE } \\
\hline $\begin{array}{l}\text { 1. Kształtowanie umiejętności } \\
\text { rozeznawania sytuacji społecz- } \\
\text { no-kulturalnej i kościelnej, w } \\
\text { której prowadzona jest działal- } \\
\text { ność duszpasterska Kościoła. } \\
\text { 2. Analiza zasad i kryteriów } \\
\text { działalności duszpasterskiej } \\
\text { Kościoła; analiza działalności } \\
\text { duszpasterskiej Kościoła oparta } \\
\text { m.in. na obserwacji i doświad- } \\
\text { czeniu zdobytym przez studen- } \\
\text { tów w trakcie praktyk zawodo- } \\
\text { wych (duszpasterskich). } \\
3 \text {. Analiza i pogłębienie zna- } \\
\text { jomości dokumentów Kościoła } \\
\text { pod kątem pastoralnym. } \\
4 \text {. Rozwijanie umiejętności } \\
\text { posługiwania się zdobytą wie- } \\
\text { dza z zakresu teologii pastoral- } \\
\text { nej w celu opracowania po- } \\
\text { szczególnych problemów; } \\
\text { kształtowanie umiejętności } \\
\text { formułowania duszpasterskich } \\
\text { wniosków i postulatów oraz } \\
\text { całościowego spojrzenia na } \\
\text { Kościół jako komunię. }\end{array}$ & $\begin{array}{l}\text { 1. Poznanie specyfiki instytucji } \\
\text { i placówek (struktury organiza- } \\
\text { cyjnej, zadań i świadczonych } \\
\text { usług, miejsca teologa we } \\
\text { wspólnocie profesjonalistów. } \\
\text { 2. Sprawdzenie się studentów } \\
\text { w praktycznym wykonywaniu } \\
\text { zadań realizowanych przez } \\
\text { placówkę np. rozpoznanie } \\
\text { palcówki pod kątem struktury } \\
\text { podopiecznych (klientów), } \\
\text { czynne uczestnictwo w pracy } \\
\text { socjalnej i poszerzenie jej o } \\
\text { warsztat pracy teologa, kształ- } \\
\text { towanie rozwoju wrażliwości } \\
\text { społecznej. }\end{array}$ & $\begin{array}{l}\text { 1. Włączenie w żywą tradycję } \\
\text { duszpasterską Kościoła lokal- } \\
\text { nego przez zdobywanie stop- } \\
\text { niowo doświadczenia w pełnie- } \\
\text { niu posługi pasterskiej, dzięki } \\
\text { której uczą się otwierać umysły } \\
\text { i serca na wymiar misyjny życia } \\
\text { Kościoła. } \\
\text { 2. Ożywienie Kościoła, będą- } \\
\text { cego z istoty swojej tajemnica, } \\
\text { komunią i misją dzięki posłu- } \\
\text { gom sprawowanym przez } \\
\text { alumnów, w ramach posługi: } \\
\text { liturgicznej, budowania wspól- } \\
\text { noty diakonalnej. } \\
\text { 3. Przygotowanie alumnów } \\
\text { jako przyszłych kapłanów do } \\
\text { służebnego przeżywania swojej } \\
\text { misji „zwierzchnika” wspólno- } \\
\text { ty oraz do unikania postaw } \\
\text { wyższości i takiego sprawowa- } \\
\text { nia władzy, które nie miałoby } \\
\text { nic wspólnego z miłością pa- } \\
\text { sterską. } \\
\text { 4. Praktykowanie form współ- } \\
\text { pracy alumnów ze sobą nawza- } \\
\text { jem oraz kapłanami, z którymi } \\
\text { w przyszłości będą pracować. }\end{array}$ \\
\hline
\end{tabular}

Na uniwersytetach udział w kształceniu pastoralnym bierze zasadniczo kilka grup studentów. Pierwszy podział studentów zależny jest od rodzaju studiów: zaoczne - dzienne. Zakres materiału, który muszą studenci przyswoić podczas studiów zaocznych jest taki sam, jak na studiach dziennych, mniejsza natomiast jest liczba zajęć dydaktycznych. Cwiczenia prowadzone dla tej grupy studentów powinny realizować podstawowy cel tej formy zajęć dydaktycznych, tj. rozwijać umiejętności posługiwania się zdobytą wiedza, zwłaszcza w sytuacjach problemowych oraz przygotować ich do prowadzenia badań. Specjalizacja kapłańska, 
katechetyczno-pastoralna i dialogu spolecznego, w ramach których odbywa się kształcenie teologiczne studentów, warunkują drugi podzial. Dla tych grup cel główny i cele pośrednie ćwiczeń pozostają takie same, natomiast cele operacyjne będą zależne od programu i specjalizacji, w ramach której prowadzone są tego typu zajęcia.

\section{III. Ćwiczenia z teologii laikatu i apostolstwa na poznańskim Wydziale Teologicznym}

Na Wydziale Teologicznym UAM w Poznaniu ćwiczenia realizowane w ramach kształcenia pastoralnego uwzględniaja przedstawione wcześniej zasady. Ćwiczenia z teologii laikatu i apostolstwa dla studentów specjalizacji katechetyczno-pastoralnej odbywają się na IV roku. Program przewiduje osiem godzin ćwiczeń, które realizuje się w blokach 90 minutowych. Jako przykład podano poniżej cel ogólny i cele pośrednie całego bloku ćwiczeń, a następnie cele operacyjne poszczególnych zajęć z uwzględnieniem metod i środków dydaktycznych. Koniecznym warunkiem do efektywnego przeprowadzenia ćwiczeń, jest odpowiednie przygotowanie studentów do zajęć. Wskazane jest zatem, aby w celu lepszego poznania grupy ćwiczeniowej pod kątem posiadanej wiedzy oraz postaw, przeprowadzić wśród uczestników $\mathrm{w}$ trakcie pierwszych zajęć anonimową ankietę związaną z tematyką ćwiczeń.

CEL OGÓLNY BLOKU ĆWICZEŃ: uzupełnienie (poszerzenie) treści wykładu przez szczegółowe zapoznanie z dokumentami Kościoła, dotyczącymi teologii laikatu i apostolstwa oraz rozwijanie umiejętności posługiwania się zdobyta wiedza.

Realizacja celu ogólnego bloku ćwiczeń dokonywana jest poprzez cele pośrednie: zapoznanie $z$ tematyką ćwiczeń oraz wymogami zaliczenia; zapoznanie z rolą laikatu na przestrzeni wieków; pogłębienie znajomości roli laikatu na podstawie tekstów Jana Pawła II; pobudzenie do refleksji związanej zaangażowaniem świeckich w Kościele; analiza pod kątem pastoralnym: Dekretu o apostolstwie świeckich Apostolicam actuositatem, Adhortacji apostolskiej Christifideles laici oraz Instrukcji o niektórych kwestiach wspótpracy wiernych świeckich $W$ posłudze ministerialnej kapłanów, rozwijanie umiejętności posługiwania się zdobytą wiedzą w celu opracowania poszczególnych problemów; kształtowanie umiejętności rozeznawania sytuacji społeczno-kulturalnej i kościelnej, w której prowadzona jest działalność duszpasterska Kościoła; umiejętność formułowania duszpasterskich wniosków i postulatów; znajomość granic możliwości współ- 
pracy świeckich z posługa kapłanów, całościowe spojrzenie na Kościól jako komunię.

ĆWICZENIE 1: Zapoznanie z historią teologii laikatu i apostolstwa.

CELE - student powinien:

- wiedzieć, jak kształtowała się rola laikatu w Kościele na przestrzeni wieków,

- wyjaśnić zależność między teologią laikatu a teologią pastoralną i eklezjologia,

- dokonać refleksji związanej z zaangażowaniem świeckich w Kościele.

METODY: krótki wykład; samodzielna analiza tekstu oraz rozwiązanie problemu; samodzielne uzupełnienie tekstu z lukami; dyskusja.

ŚRODKI DYDAKTYCZNE: folie transparentne: krótki przegląd dot. roli laikatu; 2 rodzaje zbioru tekstów dotyczacych roli laikatu na przestrzeni wieków (bez tytułów i autorów) - po jednym zestawie dla studenta oraz karta pracy; dwa teksty Ojca Świętego z lukami do uzupełnienia (jeden dla studenta) ${ }^{18}$.

ĆWICZENIE 2: Pogłębienie znajomości Dekretu o apostolstwie świeckich Apostolicam actuositatem.

CELE - student powinien:

- znać miejsce świeckiego we wspólnocie Ludu Bożego w oparciu o tekst KK 9-17; 31 oraz wymienić formy zaangażowania świeckich w Kościele na podstawie Dekretu o apostolstwie świeckich Apostolicam actuositatem,

- porównać treść dekretu z sytuacją spoleczno-kulturalną i kościelną miejscowości z której pochodzi, w celu sformułowania duszpasterskich wniosków,

- dokonać refleksji związanej z działalnością duszpasterską parafii z której pochodzi.

METODY: praca w grupach - analiza dzialalności duszpasterskiej Kościoła, formułowanie wniosków duszpasterskich; tworzenie schematu przedstawiającego treść omawianego dokumentu.

\footnotetext{
${ }^{18}$ Przykładowe środki dydaktyczne, wykorzystane podczas pierwszego ćwiczenia z teologii laikatu i apostolstwa, umieszczono w załącznikach.
} 
ŚRODKI DYDAKTYCZNE: treść Dekretu o apostolstwie świeckich Apostolicam actuositatem oraz Konstytucji dogmatycznej o Kościele Lumen gentium $(9-17 ; 31)$; folia transparentna przestawiająca schemat glównych zagadnień dokumentów; kserokopia elementów schematu dekretu; szary papier, klej, kartki, pisaki.

ĆWICZENIE 3: Pogłębienie znajomości Adhortacji apostolskiej Christifideles laici.

CELE - student powinien:

- przedstawić treść Adhortacji apostolskiej Christifideles laici,

- dokonać analizy dokumentu pod katem pastoralnym oraz sformułować duszpasterskie wnioski i postulaty,

- dokonać refleksji związanej z własnym zaangażowaniem w życie parafii.

METODY: praca w grupach - synteza dokumentu Kościoła, uzupełnienie schematu, formulowanie wniosków duszpasterskich.

ŚRODKI DYDAKTYCZNE: treść Adhortacji apostolskiej Christifideles laici; schematy do uzupełnienia głównych treści $1-3$ rozdziału omawianego dokumentu na $\mathrm{A} 3$ oraz folie transparentne ze schematami treści $1-3$ rozdziału tegoż dokumentu (dla porównania), schemat drzewa - format A3, szary papier, klej, kartki, pisaki.

ĆWICZENIE 4: Pogłębienie znajomości Instrukcji o niektórych kwestiach wspótpracy wiernych świeckich w posłudze ministerialnej kapłanów.

CELE - student powinien:

- wymienić i wyjaśnić znaczenie terminów: posługa, urząd, funkcja, kapłaństwo urzędowe, służebne, powszechne,

- przedstawić możliwości współpracy świeckich z posługą kapłanów oraz dokonać porównania treści poznanych dokumentów pod kątem wspólpracy świeckich z kaplanami,

- pogłębić swoją świadomość Kościola jako komunii. 
METODY: dyskusja, praca w grupach - porównanie zawartości dokumentów (KK, DA, ChL oraz Instrukcji) pod kątem wspólpracy świeckich z kaplanami; rozwiązywanie sytuacji problemowych.

ŚRODKI DYDAKTYCZNE: treść Instrukcji oraz wcześniej omawianych dokumentów; kartki w formacie A4, pisaki.

Dobrze przygotowane i przeprowadzone ćwiczenia wśród studentów na wyższych uczelniach $\mathrm{w}$ ramach ksztalcenia pastoralnego, są wielką szansą dla Kościoła katolickiego w Polsce. Zwłaszcza ćwiczenia z teologii laikatu i apostolstwa, gdyż w łączności z wykładem uczą analitycznego i syntetycznego spojrzenia na Kościół oraz jego działalność duszpasterska. Dają podstawy, ukazują możliwości oraz pobudzają wyobraźnię do aktywnego zaangażowania się świeckich w życie Kościoła. Kształtują one w studentach obraz Kościola jako komunii i umiejętność wykorzystywania w codziennym życiu nauki Soboru Watykańskiego II. Przygotowują świeckich do bardziej bezpośredniej współpracy z hierarchia oraz przepajania wszystkich dziedzin życia duchem Chrystusa, przez co przyczyniają się do poszerzenia przestrzeni duchowości komunii ${ }^{19}$.

\section{Załączniki}

Przedstawione poniżej przykładowe środki dydaktyczne są wykorzystywane podczas ćwiczeń z teologii laikatu i apostolstwa dla studentów IV roku specjalizacji katechetyczno-pastoralnej. Podczas zajęć studenci, wykorzystując środki dydaktyczne, mają za zadanie: przeczytać teksty (załącznik 1), napisać własny tytuł przeczytanego fragmentu, dopasować nazwisko autora (lub miejsce powstania) i tytuł do tekstu, wszystkie dane zapisać w kolejności chronologicznej na karcie pracy (załącznik 2).

\section{Załącznik 1}

Źródła tekstów zamieszczonych w załączniku:

Tekst 1: Grzegorz Wielki: Księga reguły pasterskiej. Poznań 1948 s. 32-67.

Tekst 2: Konstytucja dogmatyczna o Kościele nr 31.

Tekst 3: K. Wojtyla: Lud Boży (z przemówienia w Radio Watykańskim 25.11.1963 r.) „Przewodnik Katolicki.” R. 1964 nr 7 s. 65.

Tekst 4: Dekret Gracjana, causa XII, q 1c. 7.

\footnotetext{
${ }^{19}$ Por. Jan Paweł II: List apostolski Novo millennio ineunte. Libreria Editrice Vaticana 2001 n. 43.
} 
Tekst 5: Por. S. Sprusiński: Czy praca księdza prefekta jest „Akcja Katolickq?" "Miesięcznik Katechetyczny i Wychowawczy". R. 21: 1932 z. 4 s. $174-176$.

Tekst 6: Breviarum fidei. Wybór doktrynalnych wypowiedzi Kościoła. Red. S. Glowa, I. Bieda. Poznań 1988 s. 475—477.

Tekst 7: Jan Pawel II: List apostolski Novo millennio ineunte nr 43-46.

\section{Tekst 1:}

Postępowanie naczelnego kapłana tak dalece winno stać wyżej, niż postępowanie ludu, jak dalece różnić się zwykło życie pasterza od trzody. Trzeba bowiem, aby się starał skrzętnie uważać, jak wielka konieczność zmusza go do zachowania prawości, skoro pod jego osądem lud nazywa się trzoda. Musi więc być myślą czysty, działalnością znakomity, dyskretny w milczeniu; pożyteczny w słowie; współczuciem każdemu bardzo bliski; przede wszystkim oddany rozmyślaniu; dla dobrze czyniących towarzyszem przez skromność; przeciwko występkom grzeszących podniesiony przez gorliwość sprawiedliwości; nie zmniejszający - $\mathbf{z}$ powodu zajęcia się rzeczami zewnętrznymi - troski o rzeczy wewnętrzne; nie zaniedbujący opatrywania potrzeb zewnętrznych z powodu troskliwości o wewnętrzne. A to, czegośmy wyliczając, krótko dotknęli, rozwijając nieco szerzej wyjaśniamy.

Rządca niech będzie zawsze czysty myślą, bo żadna nieczystość nie powinna kalać tego, kto ten wzią na siẹ obowiązek, że także w cudzych sercach bẹdzie zmywał plamy zmazania; ponieważ potrzeba, aby czysta usiłowała być ręka, która stara się zmywać brudy, by za dotknięciem czegokolwiek gorzej nie brudziła, jeśli powalana ma na sobie czepiajace się jej błoto. Stąd to powiedziane jest przez proroka: „Oczyśćcie się, którzy nosicie naczynia Pańskie” Albowiem naczynia Pańskie nosza ci, którzy we wierze swego obcowania przyjmują dusze bliźnich, by je prowadzić do wiekuistych przybytków. Niech więc patrza, o ile u siebie samych winni być oczyszczani ci, którzy na łonie własnego ślubowania niosą naczynia żyjące do świątyni wieczności.

Stąd głosem bożym jest nakazane, by na piersi Aarona wyrażony był racjonał sąu z obowiązującymi go przepaskami; aby serca kapłańskiego nie trzymały w posiadaniu żadne płynne myśli, ale rozum sam powściagał; i by nie myślal czegoś nierozważnego lub niepożytecznego ten, kto postawiony na przykład innym, powagą życia powinien zawsze okazywać, jak wielki rozum nosi w piersi. 


\section{Tekst 2:}

Pod nazwą świeckich rozumie się tutaj wszystkich wiernych chrześcijan nie będących członkami stanu kapłańskiego i stanu zakonnego prawnie ustanowionego w Kościele, mianowicie wiernych chrześcijan, którzy jako wcieleni przez chrzest w Chrystusa, ustanowieni jako Lud Boży i uczynieni na swój sposób uczestnikami kapłańskiego, prorockiego i królewskiego urzędu Chrystusowego, ze swej strony sprawują właściwe całemu ludowi chrześcijańskiemu posłannictwo w Kościele i w świecie.

Właściwością specyficzną laików jest ich charakter świecki. Choć bowiem członkowie stanu kapłańskiego mogą czasem zajmować się sprawami świeckimi, wykonując nawet świeckie zawody, to z tytułu swego wyjątkowego powołania w sposób szczególny i niejako zawodowo przeznaczeni są do służby świętej, zakonnicy znów przez swój sposób życia dają wspaniałe i zaszczytne świadectwo temu, iż świat nie może się przemienić i ofiarować się Bogu bez ducha ewangelicznych blogosławieństw. Natomiast zdaniem ludzi świeckich, z tytułu właściwego im powołania, jest szukać Królestwa Bożego zajmując się sprawami świeckimi i kierując nimi po myśli Bożej. Żyją oni w świecie, to znaczy pośród wszystkich razem i poszczególnych spraw i obowiazków świata, i w zwyczajnych warunkach życia rodzinnego i społecznego, z których niejako utkana jest ich egzystencja. Tam ich Bóg powołuje, aby wykonując właściwe sobie zadania, kierowani duchem ewangelicznym przyczyniali się do uświęcenia świata na kształt zaczynu, od wewnątrz niejako, i w ten sposób przykładem zwłaszcza swego życia promieniując wiara, nadzieją i miłościa, ukazywali innym Chrystusa. Szczególnym więc ich zadaniem jest tak rozświetlać wszystkie sprawy doczesne, z którymi ściśle są związani, i tak nimi kierować, aby się ustawicznie dokonywały i rozwijały po myśli Chrystusa i aby służyły chwale Stworzyciela i Odkupiciela.

\section{Tekst 3:}

(...) Syn Boży wszedłszy w ludzkość chce nade wszystko pracować przez Kościól nad przezwyciężeniem zła; "Abyś ich zachował od złego”; tego zła, które wypacza, które wytrąca z pozycji syna Bożego. Jest w organizacji Ludu Bożego głęboko ukryte prawo walki o człowieka, o jego wartość: naturalną i nadprzyrodzoną - jak to czynił sam Chrystus. Przyzwyczailiśmy się w naszym języku posługiwać się słowem: świeccy. Świeccy, to znaczy związani ze świa- 
tem. Z tymi wartościami, które się otwieraja przed czlowiekiem w świecie, $\mathrm{z}$ jego immanentną celowością, z której wyrastają dla czlowieka różnorodne zadania. Zadanie te mają na celu rozwój świata i rozwój człowieka w świecie.

Lud Boży, i to właśnie przede wszystkim świeccy mają tutaj zadanie najbardziej bezpośrednie. Im został przede wszystkim powierzony świat. Aby wnieśli weń, we wszystkie dziedziny jego egzystencji to, co jest w Synu Bożym. A co jest w Synu Bożym? W Chrystusie jest nade wszystko: prawda i miłość. I to właśnie prawda i milość w zetknięciu ze światem, rozłożona na tyle konkretnych spraw, uczynków, sytuacji, trudności. Prawda i miłość może być w świecie wyłącznym udziałem człowieka: emanacja jego ducha. Prawda i miłość jest koniecznym warunkiem spotykania się świata z Bogiem.

Jeśli mnie ktoś zapyta: jaka jest rola świeckich w Kościele, to odpowiem, że polega ona na stałym dopełnianiu dzieła Chrystusa - Syna Bożego w świecie i przy pomocy świata. Polega na stałym odzyskiwaniu świata we wszystkich dostępnych jego rejonach i przejawach, dla Ojca Przedwiecznego. Na drodze do tego celu leży jednak jeszcze wyższy: jest to mianowicie odzyskiwanie dla Ojca Przedwiecznego samego czlowieka, w jego czlowieczeństwie. Odzyskiwanie siebie i drugich, odzyskiwanie rodzin i wspólnot, środowisk, szczepów czy plemion, wsi i miast, narodów i państw. I odzyskiwanie dla tego Ojca - do którego zwracamy się w modlitwie z przydawką: „nasz” - tylu różnych form ludzkiej pracy, twórczości, miłości, badań i poszukiwań, rozrywki i odpoczynku wszystkiego wreszcie, co nosi na sobie znamię życia i działalności człowieka.

Rola laikatu w Kościele ma swoją własną specyfikę. Na miarę współczesności, na miarę ludzkich możliwości. I powiedziałbym także: na miarę ludzkiej słabości. To wszystko już wyraziło się w Ewangelii. Świeccy od swej strony tworzą Kościól. Tworzą - to znaczy są twórczy, twórczością calego swojego życia: pracy, radości, odpoczynku czy cierpienia. A źródłem tej twórczości jest Ewangelia gruntownie odczytana. I źródłem jest Łaska rozwijająca się w duszy na miarę własnego stanu na powołania.

Rola świeckich w Kościele choć odrębna, jest jednak zespolona z rolą duchownych. Zadanie bezpośrednie tych ostatnich stanowi słowo Ewangelii i środki Łaski przy pomocy których świeccy odzyskują świat dla Ojca. To ścisłe połączenie duchownych ze świeckimi w Kościele jest znamieniem charakterystycznym Ludu Bożego. U jego początku stoi Chrystus-Kaplan. Katolicy żyjący w świecie muszą dziś w ogromnej mierze odzyskać świadomość tego udziału, jaki im przypada w Kapłaństwie Chrystusa - to znaczy przemyśleć gruntownie fakt swojego chrztu i bierzmowania. Wszystko to, aby nie pozbawić się poczucie wielkiego powołania i żeby dobrze spełnić rolę w Kościele. 


\section{Tekst 4:}

Istnieją dwa rodzaje chrześcijan duchowni i świeccy. Jeden rodzaj stanowia ci, którzy sprawują służbę Boża, oddają się kontemplacji i modlitwie. Są to duchowni i zakonnicy. Drugi rodzaj chrześcijan - to są świeccy. Oni moga posiadać dobra doczesne. Wolno im żenić się, uprawiać ziemie, prowadzić sądy, prawować się, składać ofiary na ołtarze, placić dziesięciny, i w ten sposób będą mogli się zbawić, o ile czyniąc dobrze, unikać będą występków.

\section{Tekst 5:}

Akcja katolicka nie wnosi nowych idei, bo apostolstwo jest od początku chrześcijaństwa. Koniecznem jest, by Akcja Katolicka korzystała ze stosownej chwili i szła odważnie naprzód, by dała wyraz swoim poglqdom i obwieściła je przez wytrwałq, czynnq rozumnq i karnq propagandę, zdolnq przeciwstawiać się propagandzie przeciwnej (Leona XIII: Encyklika Graves de communi). Każdy proboszcz musi w swej parafii przygotować i zorganizować stowarzyszenia Akcji Katolickiej, które sq ramionami dodanemi przez Boga i Kościół do umysłu i serca proboszcza. Wypełnianie obowiązków duszpasterskich jest podstawowym i pierwszym zadaniem każdego kapłana. Udzielanie się kaplanów w organizacjach kościelnych - to jest akcją katolicką.

\section{Tekst 6:}

A jeśli ktoś twierdzil, że wszyscy bez różnicy chrześcijanie są obdarzeni równą między sobą władzą duchową, ten zdaje się nic innego nie czynić, jak wprowadzać nieład w hierarchię kościelną [kan. 6], która jest „jako uporządkowany szyk bojowy" [Pnp 6, 3], tak jak gdyby wbrew nauce św. Pawła wszyscy byli apostołami, wszyscy prorokami, wszyscy ewangelistami, wszyscy pasterzami, wszyscy doktorami [por. 1Kor 12, 29; Ef 4, 11](...). Przeto naucza święty Sobór, ze do wyświęcenia biskupów, kapłanów i duchownych innych stopni nie jest wymagana zgoda, upoważnienie czy zaproszenie ze strony ludu, władzy świeckiej lub urzędów, jak gdyby bez nich świecenia nie miały wartości. Przeciwnie, postanawia, że wszyscy ci, co powołani lub ustanowieni tylko przez lud, świecką władzę lub urząd przystępują do wykonywania tych posług, jak i ci, co kierowani własną lekkomyślnością sami do niech przystępuja, winni być uważani nie za sługi Kościoła, lecz za „złodziei i rozbójników nie wchodzących przez 
drzwi" [J 10, 1; kan.8] Oto sa rzeczy, co do których święty Sobór uważal za wskazane pouczyć ogólnie wiernych Chrystusa o sakramencie kapłaństwa. Przeciwne zaś opinie postanowił odrzucić w kanonach jasnych i szczegółowych, jak to jest dalej podane, aby wszyscy z pomoca Chrystusa, idąc za drogowskazem wiary, mogli łatwiej rozpoznać wśród nocy tylu błędów prawdę katolicką oraz ją zachować.

\section{Tekst 7:}

(...) wizja komunii jest ściśle związana za zdolnością chrześcijańskiej wspólnoty do otwarcia się na wszystkie dary Ducha. Jedność Kościoła nie oznacza jednolitości, ale połączenie w organiczną całość uprawnionych odmienności. Jest to rzeczywistości wielu członków polączonych w jednym Ciele - jednym ciele Chrystusa (por. 1 Kor 12, 12). Jest zatem konieczne, aby Kościól trzeciego tysiąclecia pobudzal wszystkich ochrzczonych i bierzmowanych do uświadomienia sobie obowiązku czynnego udziały w życiu kościelnym. Obok posługi kapłańskiej także inne posługi ustanowione lub po prostu uznane - mogą się rozwijać z pożytkiem dla całej wspólnoty, zaspokajając jej wielorakie potrzeby: od katechezy po aktywny udzial w liturgii, od wychowania młodzieży po różne formy działalności charytatywnej. Z pewnością należy też wielkodusznie wspomagać powołania do kapłaństwa i do szczególnej konsekracji, przede wszystkim przez modlitwę do pan żniwa (por. Mt 9, 38). Jest to sprawa bardzo istotna dla życia Kościoła we wszystkich częściach świata. (...) Należy zwłaszcza coraz bardziej lepiej odkrywać znaczenie powołania właściwego świeckim, którzy jako tacy sa wezwani, aby „szukać królestwa Bożego zajmując się sprawami świeckimi i kierując się nimi po myśli Bożej”, a także mieć „swój udział w posłannictwie calego Ludu Bożego w Kościele i w świecie (...) przez swoją pracę zmierzająca do szerzenia Ewangelii oraz uświęcania ludzi”. Na tej samej zasadzie bardzo ważnym dla komunii jest obowiązek popierania różnych form zrzeszania się zarówno tradycyjnych, jak i nowszych ruchów kościelnych, ponieważ nadają one Kościołowi żywotność, która jest darem Bożym i przejawem prawdziwej „wiosny Ducha". 


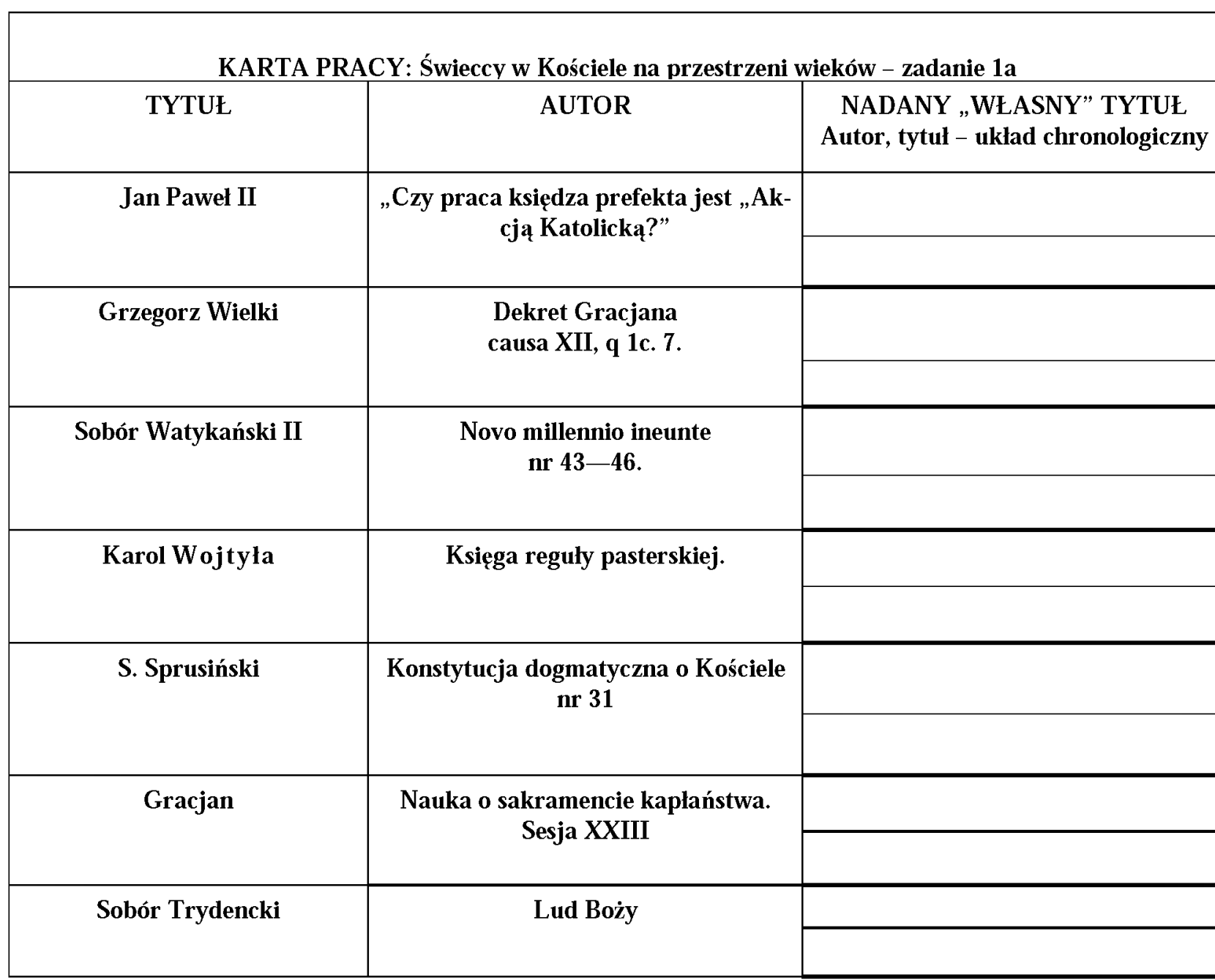

